\title{
End-Of-Life Discussions Reduce The Utilization of Life-Sustaining Treatments During The Last Three Months of Life in Cancer Patients : A Nationwide Population-Based Cohort Study
}

\section{Shang-Yih Chan}

Taipei City Hospital Yangming Branch

\section{Yun-Ju Lai}

Puli VH: Taichung Veterans General Hospital Puli Branch

\section{Yu-Yen Hsin Chen}

Taichung Veterans General Hospital

\section{Shuo-Ju Chiang}

Taipei City Hospital Yangming Branch

\section{Yi-Fan Tsai}

Taipei City Hospital Yangming Branch

\section{Li-Fei Hsu}

National Taiwan University

\section{Pei-Hung Chuang}

Taipei Association of Health and Welfare Data Science, Taiwan

\section{Chu-Chieh Hsin Chen}

National Taipei University of Nursing and Health Sciences - Ming De Road Campus: National Taipei University of Nursing and Health Sciences

\section{Yung-Feng Yen ( $\nabla$ yfyen1@gmail.com )}

Taipei City Hospital Yangming Branch https://orcid.org/0000-0002-4469-4732

\section{Research Article}

Keywords: cancer patients, end-of-life discussions, life-sustaining treatments, cohort study

Posted Date: August 9th, 2021

DOl: https://doi.org/10.21203/rs.3.rs-634427/v1

License: (9) (1) This work is licensed under a Creative Commons Attribution 4.0 International License. Read Full License 


\section{Abstract \\ Purpose}

Studies to examine the impact of end-of-life (EOL) discussions on the utilization of life-sustaining treatments near death were limited and had inconsistent findings. This nationwide population-based cohort study determined the impact of EOL discussions on the utilization of life-sustaining treatments in the last three months of life in Taiwanese cancer patients.

\section{Methods}

This cohort study included adult cancer patients from 2012-2018, which were confirmed by pathohistological reports. Life-sustaining treatments during the last three months of life included cardiopulmonary resuscitation, intubation, and defibrillation. EOL discussions in cancer patients were confirmed by their medical records. Association of EOL discussions with utilization of life-sustaining treatments were assessed using multiple logistic regression.

\section{Results}

Of 381,207 patients, the mean age was 70.5 years and $19.4 \%$ of the subjects utilized life-sustaining treatments during the last three months of life. After adjusting for other covariates, those who underwent EOL discussions were less likely to receive life-sustaining treatments during the last three months of life compared to those who did not (Adjusted odds ratio [AOR]: $0.82 ; 95 \%$ confidence interval [Cl]: $0.80-0.84$ ). Considering the type of treatments, EOL discussions correlated with a lower likelihood of receiving cardiopulmonary resuscitation ( $\mathrm{AOR}=0.43,95 \% \mathrm{Cl}$ : $0.41-0.45)$, endotracheal intubation ( $\mathrm{AOR}=0.87$, $95 \% \mathrm{Cl}: 0.85-0.89)$, and defibrillation (AOR $=0.52,95 \% \mathrm{Cl}: 0.48-0.57)$.

\section{Conclusion}

EOL discussions correlated with a lower utilization of life-sustaining treatments during the last three months of life among cancer patients. Our study supports the importance of providing these discussions to cancer patients to better align care with preferences during the EOL treatment.

\section{Background}

Cancer is the second leading cause of death worldwide, and was responsible for an estimated 10 million deaths in 2020 [1]. Patients often experience pain, dyspnea, and distress during the end-of-life (EOL) care. Aggressive EOL treatment has predicted lower quality of life $[2,3]$ and greater regret about treatment decisions [4]. 
Comprehensive EOL discussions with physicians could allow cancer patients to confront the limitations of medical treatments and consider their preferences regarding life-sustaining treatments in extremis. A meta-analysis review showed that these discussions predicted an increased use of hospice care and better quality of death [5]. However, cancer patients often ignore the provision of EOL discussions [6, 7] and initiate them late in the disease's progression [8].

Although EOL discussions offer patients the opportunity to define their expectations for life-sustaining treatments that they want to receive in extremis, studies to examine the impact of EOL discussions on the utilization of life-sustaining treatments near death were limited and had inconsistent findings. A US cohort study followed up 332 patients with advanced cancer and found that patients who participated in EOL discussions were less likely to receive ventilation (Adjusted odds ratio [AOR]: 0.26; 95\% confidence interval [Cl]: 0.08-0.83) and resuscitation (AOR 0.16, 95\% $\mathrm{Cl} 0.03-0.80$ ) during the EOL treatment compared to those who did not [6]. In another observational study in the US involving 145 patients with advanced cancer, EOL discussions significantly correlated with a lower rate of receiving ventilation (AOR $0.03,95 \% \mathrm{Cl} 0.002-0.3$ ) but did not significantly associate with a lower rate of resuscitation (AOR $0.1,95 \%$ $\mathrm{Cl}$ 0.02-1.3) [2]. Previous studies on the association between EOL discussions and the use of lifesustaining treatment, however, have used small sample sizes $(n=145)$ [2] and inadequately controlled for potential confounders such as dementia $[2,6]$.

EOL discussions serve to maximize patients' quality of life while considering their goals and expectations regarding EOL treatment. It is important to understand the impact of these discussions on the administration of life-sustaining treatments among terminally ill patients. We therefore conducted a nationwide population-based cohort study to determine the impact of EOL discussions on the utilization of life-sustaining treatments in extremis among Taiwanese cancer patients, from 2012-2018.

\section{Methods}

\section{Promotion of end-of-life discussions in terminally ill patients in Taiwan}

The Taiwan National Health Insurance Administration, since 2012, has initiated an EOL discussions program that encourages healthcare providers to provide these discussions to terminally ill patients [9]. During the discussions, healthcare providers discuss patients' goals and preferences concerning medical care and life-sustaining treatments towards the end of their lives [9]. Each EOL discussion with a patient awards the healthcare provider with the equivalent of US\$75 [9]. There should be a record of all discussion content in the patient's medical chart and each session must be at least an hour long [9].

\section{Study population}

This nationwide cohort study used the Taiwan National Health Insurance Research Database (NHIRD), which contains healthcare data from more than $99 \%$ of the population in Taiwan [10]. It is a large-scale database derived from the national health insurance system, which consists of registration files and 
original claims data. The database de-identified and scrambled the patients' identification codes before releasing the data for research purposes [11].

This cohort study selected subjects aged 18 years or older who had received a cancer diagnosis and died between January 1, 2012 and December 31, 2018. We identified these patients from the Registry for Catastrophic Illness. In Taiwan, the Registry for Catastrophic Illness requires a peer review of pathohistological reports before a cancer diagnosis is reported [12]. This registry was also linked to Taiwan's death certificate database to confirm the demise of cancer patients [13]. The Institutional Review Board of TCH (no. TCHIRB-10709107-W) approved this study and we performed all methods in accordance with TCH IRB guidelines and regulations.

\section{Outcome variable}

The outcome was life-sustaining treatments during the last three months of life in cancer patients. Lifesustaining treatments included cardiopulmonary resuscitation, intubation, and defibrillation [14].

\section{Main explanatory variable}

The main explanatory variable was EOL discussions with physicians, which was determined by patients' medical records.

\section{Controlling variables}

The controlling variables included sociodemographic characteristics and comorbidities. Sociodemographic factors included age, sex, urbanization, and income level. Urbanization described whether subjects resided in urban, suburban, or rural areas [15]. We calculated the income level from the average monthly income of the insured person and grouped it into three categories: low ( $\leq$ 19,200 New Taiwan Dollars [NTD]), intermediate (19,201 NTD to $<40,000$ NTD), and high ( $\geq 40,000$ NTD). We defined the comorbidities according to the International Classification of Diseases, Ninth and Tenth Revision, Clinical Modification (ICD-9-CM and ICD-10-CM) code. Subjects' comorbidities include diabetes, chronic kidney disease, congestive heart failure, coronary heart disease, liver cirrhosis, chronic obstructive pulmonary disease, dementia, and cerebrovascular disease (Supplementary table 1). A person was considered to have a comorbidity only if the condition occurred in an inpatient setting or in three or more outpatient visits [16].

\section{Statistical analysis}

First, we analyzed the subjects' demographic data. We then analyzed categorical data using the Pearson

$\chi^{2}$ test where appropriate. We presented continuous data as mean \pm standard deviation (SD), and conducted a two-sample t-test to compare outcomes between patients who underwent EOL discussions and those who did not. 
We assessed the crude associations of EOL discussions and other covariates with the outcome (utilization of life-sustaining treatments during the last three months of life) by computing the odds ratios (ORs) and corresponding 95\% confidence intervals (Cls). We then performed a multivariate logistic regression to estimate the association between EOL discussions and the utilization of life-sustaining treatments after adjusting for potential confounders. A variable with $p<0.05$ was defined as a significant factor associated with the utilization of life-sustaining treatments in the multivariate analysis. Adjusted odds ratios (AOR) with $95 \%$ confidence intervals $(\mathrm{Cl})$ indicated the strength and direction of these associations.

We conducted subgroup and sensitivity analyses to examine the robustness of the main findings, after stratifying participants by age and sex. We performed all data management and analyses using the SAS ${ }^{\circledR}$ v9.4 statistical software package (SAS Institute, Cary, NC, USA).

\section{Results}

\section{Participant selection}

This cohort study involved the raw data of 383,128 deceased cancer patients from 1 January 2012 to 31 December 2018. After excluding those younger than 15 years $(n=850)$ and those with missing data ( $n=1071), 381,207$ patients were eligible for the purposes of the study. The overall mean (SD) age was 70.5 (14.3) years; $65.6 \%$ of the subjects were male; and $14.1 \%$ of the subjects had EOL discussions with healthcare providers towards the end of their lives.

\section{Characteristics of patients by end-of-life discussions}

Table 1 shows the characteristics of cancer patients with and without EOL discussions before death. The patients who participated in EOL discussions tended to be younger and were more likely to be female. During the follow-up period, 74,034 patients utilized life-sustaining treatments during their last three months of life, including 9,048 (16.82\%) patients who had EOL discussions and 64,986 (19.85\%) who did not have EOL discussions.

\section{Association of end-of-life discussions with utilization of life-sustaining treatments}

Table 2 shows the univariate and multivariate analyses of factors associated with life-sustaining treatments during the last three months of life among the cancer patients. After adjusting for the sociodemographic factors and co-morbidities, those who underwent EOL discussions were less likely to receive life-sustaining treatments during the last three months of life, compared to those who did not (AOR=0.82, 95\% Cl: 0.80-0.84).

Association of end-of-life discussions with cardiopulmonary resuscitation, endotracheal intubation, and defibrillation 
Table 3 shows the multivariate analyses for the association of EOL discussions with cardiopulmonary resuscitation, endotracheal intubation, and defibrillation in cancer patients. After adjusting for the sociodemographic factors and co-morbidities, patients who underwent EOL discussions were less likely to receive cardiopulmonary resuscitation during their last three months of life, compared to those who did not (AOR=0.43, 95\% Cl: 0.41-0.45). Moreover, those who participated in EOL discussions had a lower likelihood of receiving endotracheal intubation (AOR=0.87, 95\% $\mathrm{Cl}$ : 0.85-0.89) and defibrillation $(\mathrm{AOR}=0.52,95 \% \mathrm{Cl}: 0.48-0.57)$ during the last three months of life, compared to those who did not.

\section{Subgroup and sensitivity analysis for the association between end-of-life discussions and life-sustaining treatments}

Table 4 shows the results of subgroup analyses of the association between EOL discussions and lifesustaining treatments after stratifying participants by age and sex. In all patient subgroups, the discussions significantly predicted a lower likelihood of receiving life-sustaining treatments towards the end of life.

\section{Discussion}

This nationwide cohort study found that $19.4 \%$ of cancer patients utilized life-sustaining treatments during the last three months of life. After adjusting for demographic data and comorbidities, cancer patients who underwent EOL discussions were less likely to receive life-sustaining treatments during EOL care. With regard to the treatment types, EOL discussions predicted a lower likelihood of receiving cardiopulmonary resuscitation, endotracheal intubation, and defibrillation towards the end of the patients' lives.

Our study revealed robust associations between EOL discussions and life-sustaining treatments after stratifying patients by age and sex. In all patient subgroups, the discussions significantly lowered the likelihood of receiving life-sustaining treatments near death.

This study found that $14.1 \%$ of cancer patients in Taiwan participated in EOL discussions, which was lower than $37.0 \%$ among cancer patients in the US [6]. These discussions provide patients the opportunity to define their goals and expectations regarding the medical care that they would like to receive in extremis [17]. Since EOL discussions with physicians comprehensively informed patients' wishes with respect to EOL care, our study suggests that it is imperative to provide such discussions for cancer patients nearing the end of their lives.

The present cohort study found that cancer patients who underwent EOL discussions had $18 \%$ lower rates of receiving life-sustaining treatments in the last three months of life, than those who did not.

Although EOL discussions offer patients the opportunity to define their preferences regarding lifesustaining treatments in extremis, the impact of EOL discussions on the utilization of life-sustaining treatments near death has not been extensively studied. A study in the US found that EOL discussions 
correlated with lower rates of ventilation and resuscitation near death [6]. Another study in the US analyzed 145 cancer patients and found that patients who had undergone EOL discussions were less likely to receive ventilation in the last week of life, but were not less likely to receive resuscitation in the same timeframe [2]. Our cohort study followed up 381,207 cancer patients and found that EOL discussions associated with a lower utilization of life-sustaining treatments during the last three months of life. With regard to treatment types, cancer patients who had EOL discussions had a lower likelihood of receiving cardiopulmonary resuscitation, endotracheal intubation, and defibrillation during EOL care. Thus the findings of our study suggest that EOL discussions could reduce the utilization of life-sustaining treatments in cancer patients near death.

The EOL conversations with physicians improved the patients' understanding of the benefits of aggressive therapies during EOL care. This may account for the lower rate of receiving life-sustaining treatments at that stage. While cancer patients had EOL discussions with physicians, the benefit and harm of life-sustaining treatments during the EOL care would be discussed and emphasized. Through the EOL discussions with healthcare providers, cancer patients could consider and document their treatment preferences during EOL care. A prior study showed that EOL discussions significantly improved patients' understanding of their terminal illness and subsequently reduced the likelihood of receiving aggressive treatments during EOL care [18]. Since EOL discussions improved patient satisfaction and quality of care $[19,20]$, the findings of our study suggest that it is important to provide them to better align care with preferences during EOL treatment.

This nationwide cohort study has several strengths. First, this study is the largest cohort study to determine the impact of EOL discussions on the utilization of life-sustaining treatments during the last three months of life among cancer patients. The research design enhances the validity of our findings by including unbiased subject selection and strict cancer diagnostic criteria. Moreover, since the Taiwan National Health Insurance covers all medical care of cancer patients, this nationwide population-based study traced all cancer patients, thus minimizing referral bias. Furthermore, the study's large sample size sufficiently detected the real, albeit subtle, difference between cancer patients who had and those who had not received EOL discussions towards the end of their lives.

This cohort study has two limitations. First, there may be important factors (e.g., patients' religion) associated with the decision of receiving life-sustaining treatments, which the National Health Insurance Research Database did not record. Second, since all our enrollees were Taiwanese, the external validity of our findings may be a concern. Therefore, the generalizability of our results to other non-Asian ethnic groups requires further verification. However, our findings suggest new avenues for future research.

\section{Conclusions}

This nationwide, cohort study found that cancer patients who had EOL discussions were less likely to receive life-sustaining treatments during the last three months of life compared to those who did not have EOL discussions. With regard to treatment types, EOL discussions correlated with a lower likelihood of 
receiving cardiopulmonary resuscitation, endotracheal intubation, and defibrillation during the last three months of life. Since EOL discussions improve patient quality of care, the findings of our study suggest that it is important to provide them to better align care with preferences during EOL treatment.

\section{Declarations}

Funding This study was supported by the grants from Puli Branch of Taichung Veterans General Hospital, Taiwan (grant number: PL-2018011) and Department of Health, Taipei City Government, Taiwan (No. 10801-62-006; No. TPCH-110-45). The funders had no role in the design and conduct of the study; collection, management, analysis, and interpretation of the data; preparation, review, or approval of the manuscript; and decision to submit the manuscript for publication.

Conflicts of interest/Competing interests The authors declare that they have no conflict of interest.

Availability of data and material This nationwide cohort study used the Taiwan National Health Insurance Research Database (NHIRD). With approval from the National Health Research Institutes, the NHIRD was accessed at the Collaboration Center of Health Information Application, Department of Health, Executive Yuan, Taiwan.

\section{Code availability N/A}

Authors' contributions Shang-Yih Chan, Yun-Ju Lai, Yu-Yen Chen, Shuo-Ju Chiang, Yi-Fan Tsai, Li-Fei Hsu, Pei-Hung Chuang, Chu-Chieh Chen, and Yung-Feng Yen substantially contributed to the conception and design of the study, data analysis, data interpretation, and the drafting of the manuscript. Shang-Yih Chan, Yun-Ju Lai, Yu-Yen Chen, Yi-Fan Tsai, Li-Fei Hsu, Pei-Hung Chuang, Chu-Chieh Chen, and Yung-Feng Yen substantially contributed to data acquisition and interpretation of the results. Shang-Yih Chan, YunJu Lai, Yu-Yen Chen, Shuo-Ju Chiang, Yi-Fan Tsai, Li-Fei Hsu, Pei-Hung Chuang, Chu-Chieh Chen, and Yung-Feng Yen all approved the final version of the manuscript.

Ethics approval This study was approved by the Institutional Review Board of TCH (no. TCHIRB10709107-W) and all methods were performed in accordance with TCH IRB guidelines and regulations.

\section{Consent to participate N/A}

Consent for publication N/A

\section{References}

1. WHO: Cancer-Key facts (2020) Available at: https://www.who.int/news-room/factsheets/detail/cancer. [accessed 1 June 2021]

2. Zhang B, Wright AA, Huskamp HA, Nilsson ME, Maciejewski ML, Earle CC, Block SD, Maciejewski PK, Prigerson HG (2009) Health care costs in the last week of life: associations with end-of-life 
conversations. Arch Intern Med 169(5):480-488. https://doi.org/10.1001/archinternmed.2008.587

3. Wachterman MW, Pilver C, Smith D, Ersek M, Lipsitz SR, Keating NL (2016) Quality of End-of-Life Care Provided to Patients With Different Serious IIInesses. JAMA internal medicine 176(8):10951102. https://doi.org/10.1001/jamainternmed.2016.1200

4. Smith-Howell ER, Hickman SE, Meghani SH, Perkins SM, Rawl SM (2016) End-of-Life Decision Making and Communication of Bereaved Family Members of African Americans with Serious IIIness. J Palliat Med 19(2):174-182. https://doi.org/10.1089/jpm.2015.0314

5. Starr LT, Ulrich CM, Corey KL, Meghani SH (2019) Associations Among End-of-Life Discussions, Health-Care Utilization, and Costs in Persons With Advanced Cancer: A Systematic Review. Am J Hosp palliat Care 36(10):913-926. https://doi.org/10.1177/1049909119848148

6. Wright AA, Zhang B, Ray A, Mack JW, Trice E, Balboni T, Mitchell SL, Jackson VA, Block SD, Maciejewski PK, Prigerson HG (2008) Associations between end-of-life discussions, patient mental health, medical care near death, and caregiver bereavement adjustment. Jama 300(14):1665-1673. https://doi.org/10.1001/jama.300.14.1665

7. Baile WF, Lenzi R, Parker PA, Buckman R, Cohen L (2002) Oncologists' attitudes toward and practices in giving bad news: an exploratory study. Journal of clinical oncology: official journal of the American Society of Clinical Oncology 20(8):2189-2196. https://doi.org/10.1200/JC0.2002.08.004

8. Lopez-Acevedo M, Havrilesky LJ, Broadwater G, Kamal AH, Abernethy AP, Berchuck A, Alvarez Secord A, Tulsky JA, Valea F, Lee PS (2013) Timing of end-of-life care discussion with performance on endof-life quality indicators in ovarian cancer. Gynecol Oncol 130(1):156-161. https://doi.org/10.1016/j.ygyno.2013.04.010

9. Ministry of Health and Welfare, Taiwan: promotion of end-of-life discussions in terminally ill patients. https://www.mohw.gov.tw/cp-2641-21123-1.html [accessed 28 June 2021] [Chinese]

10. Wu CY, Chen YJ, Ho HJ, Hsu YC, Kuo KN, Wu MS, Lin JT (2012) Association between nucleoside analogues and risk of hepatitis $B$ virus-related hepatocellular carcinoma recurrence following liver resection. JAMA 308(18):1906-1914. https://doi.org/10.1001/2012.jama.11975

11. National Health Insurance Research Database, Taiwan. http://nhird.nhri.org.tw/ [accessed 15 April 2016]

12. Su VY, Yen YF, Pan SW, Chuang PH, Feng JY, Chou KT, Chen YM, Chen TJ, Su WJ (2016) Latent Tuberculosis Infection and the Risk of Subsequent Cancer. Medicine 95(4):e2352. https://doi.org/10.1097/MD.0000000000002352

13. Department of Health (1971) Vital Statistics in Taiwan. Department of Health, Executive Yuan, Taiwan

14. Quill CM, Ratcliffe SJ, Harhay MO, Halpern SD (2014) Variation in decisions to forgo life-sustaining therapies in US ICUs. Chest 146(3):573-582. https://doi.org/10.1378/chest.13-2529

15. Yadav KN, Gabler NB, Cooney E, Kent S, Kim J, Herbst N, Mante A, Halpern SD, Courtright KR (2017) Approximately One In Three US Adults Completes Any Type Of Advance Directive For End-Of-Life Care. Health Aff 36(7):1244-1251. https://doi.org/10.1377/hlthaff.2017.0175 
16. Yen YF, Chung MS, Hu HY, Lai YJ, Huang LY, Lin YS, Chou P, Deng CY (2015) Association of pulmonary tuberculosis and ethambutol with incident depressive disorder: a nationwide, populationbased cohort study. J Clin Psychiatry 76(4):e505-e511. https://doi.org/10.4088/JCP.14m09403

17. Myers J (2015) Improving the quality of end-of-life discussions. Curr Opin Support Palliat Care 9(1):72-76. https://doi.org/10.1097/SPC.0000000000000108

18. Prigerson HG (1992) Socialization to dying: social determinants of death acknowledgement and treatment among terminally ill geriatric patients. Journal of health social behavior 33(4):378-395

19. Covinsky KE, Fuller JD, Yaffe K, Johnston CB, Hamel MB, Lynn J, Teno JM, Phillips RS (2000) Communication and decision-making in seriously ill patients: findings of the SUPPORT project. The Study to Understand Prognoses and Preferences for Outcomes and Risks of Treatments. J Am Geriatr Soc 48(S1):S187-S193. https://doi.org/10.1111/j.1532-5415.2000.tb03131.x

20. Foley K (2000) Dismantling the barriers: providing palliative and pain care. Jama 283(1):115

\section{Tables}


Table 1

Characteristics of deceased cancer patients by end-of-life discussions

\begin{tabular}{|c|c|c|c|c|}
\hline \multirow[t]{2}{*}{ Characteristics } & \multicolumn{3}{|c|}{ No. $(\%)$ of subjects ${ }^{*}$} & \multirow{2}{*}{$\begin{array}{l}\mathrm{P} \\
\text { value }\end{array}$} \\
\hline & $\begin{array}{l}\text { Total, N } \\
= \\
381207\end{array}$ & $\begin{array}{l}\text { Patients with EOL } \\
\text { discussions, } n= \\
53783\end{array}$ & $\begin{array}{l}\text { Patients without EOL } \\
\text { discussions, } n= \\
327424\end{array}$ & \\
\hline \multicolumn{5}{|l|}{ Demographics } \\
\hline \multicolumn{5}{|l|}{ Age, yrs } \\
\hline Mean \pm SD & $\begin{array}{l}70.46 \pm \\
14.26\end{array}$ & $69.19 \pm 14.21$ & $70.66 \pm 14.26$ & $<.001$ \\
\hline $18-64$ & $\begin{array}{l}131034 \\
(34.37)\end{array}$ & 20302 (37.75) & 110,732 (33.82) & $<.001$ \\
\hline$\geq 65$ & $\begin{array}{l}250173 \\
(65.63)\end{array}$ & $33,481(62.25)$ & $216,692(66.18)$ & \\
\hline Sex & & & & $<.001$ \\
\hline Female & $\begin{array}{l}147147 \\
(38.60)\end{array}$ & 21,226 (39.47) & $125,921(38.46)$ & \\
\hline Male & $\begin{array}{l}234060 \\
(61.40)\end{array}$ & $32,557(60.53)$ & $201,503(61.54)$ & \\
\hline Income level & & & & $<.001$ \\
\hline Low & $\begin{array}{l}64059 \\
(16.80)\end{array}$ & $8,745(16.26)$ & $55,314(16.89)$ & \\
\hline Intermediate & $\begin{array}{l}195861 \\
(51.38)\end{array}$ & $26,823(49.87)$ & 169,038 (51.63) & \\
\hline High & $\begin{array}{l}121287 \\
(31.82)\end{array}$ & 18,215 (33.87) & $103,072(31.48)$ & \\
\hline Urbanization & & & & $<.001$ \\
\hline Rural & $\begin{array}{l}44575 \\
(11.69)\end{array}$ & $5,358(9.96)$ & 39,217 (11.98) & \\
\hline Suburban & $\begin{array}{l}232349 \\
(60.95)\end{array}$ & $32,814(61.01)$ & $199,535(60.94)$ & \\
\hline Urban & $\begin{array}{l}104283 \\
(27.36)\end{array}$ & $15,611(29.03)$ & $88,672(27.08)$ & \\
\hline \multicolumn{5}{|l|}{ Comorbidity } \\
\hline Diabetes & $\begin{array}{l}135886 \\
(35.65)\end{array}$ & 19,087 (35.49) & $116,799(35.67)$ & 0.411 \\
\hline
\end{tabular}




\begin{tabular}{|c|c|c|c|c|}
\hline \multirow[t]{2}{*}{ Characteristics } & \multicolumn{3}{|c|}{ No. $(\%)$ of subjects ${ }^{*}$} & \multirow{2}{*}{$\begin{array}{l}\mathrm{P} \\
\text { value }\end{array}$} \\
\hline & $\begin{array}{l}\text { Total, N } \\
= \\
381207\end{array}$ & $\begin{array}{l}\text { Patients with EOL } \\
\text { discussions, } \mathrm{n}= \\
53783\end{array}$ & $\begin{array}{l}\text { Patients without EOL } \\
\text { discussions, } n= \\
327424\end{array}$ & \\
\hline Chronic kidney disease & $\begin{array}{l}87396 \\
(22.93)\end{array}$ & $11,282(20.98)$ & $76,114(23.25)$ & $<.001$ \\
\hline Congestive heart failure & $\begin{array}{l}59996 \\
(15.74)\end{array}$ & 7,786 (14.48) & $52,210(15.95)$ & $<.001$ \\
\hline Coronary heart disease & $\begin{array}{l}124070 \\
(32.55)\end{array}$ & $16,296(30.30)$ & $107,774(32.92)$ & $<.001$ \\
\hline Liver cirrhosis & $\begin{array}{l}57255 \\
(15.02)\end{array}$ & $7,697(14.31)$ & $49,558(15.14)$ & $<.001$ \\
\hline COPD & $\begin{array}{l}118345 \\
(31.04)\end{array}$ & $15,677(29.15)$ & $102,668(31.36)$ & $<.001$ \\
\hline Dementia & $\begin{array}{l}37402 \\
(9.81)\end{array}$ & $4,790(8.91)$ & $32,612(9.96)$ & $<.001$ \\
\hline Cerebrovascular disease & $\begin{array}{l}102614 \\
(26.92)\end{array}$ & $13,501(25.10)$ & $89,113(27.22)$ & $<.001$ \\
\hline \multicolumn{5}{|l|}{ Outcome } \\
\hline $\begin{array}{l}\text { Life-sustaining treatments } \\
\text { during the last } 3 \text { months of } \\
\text { life }\end{array}$ & $\begin{array}{l}74034 \\
(19.42)\end{array}$ & $9048(16.82)$ & 64986 (19.85) & $<.001$ \\
\hline Endotracheal intubation & 66,861 & $8,483(15.77)$ & $58,378(17.83)$ & $<.001$ \\
\hline $\begin{array}{l}\text { Cardiopulmonary } \\
\text { resuscitation }\end{array}$ & 32,739 & $2,269(4.22)$ & $30,470(9.31)$ & $<.001$ \\
\hline Defibrillation & 6,493 & $514(0.96)$ & $5,979(1.83)$ & $<.001$ \\
\hline
\end{tabular}


Table 2

Univariate and multivariate analysis of factors associated with utilization of life-sustaining treatments during the last 3 months of life among deceased cancer patients

\begin{tabular}{|c|c|c|c|c|}
\hline \multirow[t]{2}{*}{ Variables } & \multirow[t]{2}{*}{$\begin{array}{l}\text { Number of } \\
\text { patients }\end{array}$} & \multirow{2}{*}{ 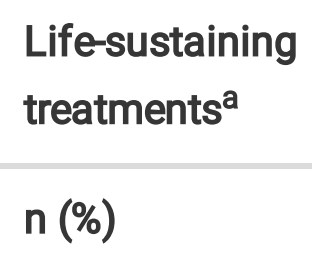 } & Univariate & \multirow{2}{*}{$\begin{array}{l}\text { Multivariate } \\
\text { analysis }\end{array}$} \\
\hline & & & OR $(95 \% \mathrm{Cl})$ & \\
\hline \multicolumn{5}{|c|}{ EOL discussions } \\
\hline No & 327,424 & 64986 (19.85) & 1 & 1 \\
\hline Yes & 53,783 & $9048(16.82)$ & $\begin{array}{l}0.82(0.80- \\
0.84)^{\star \star \star}\end{array}$ & $\begin{array}{l}0.82(0.80- \\
0.84)^{\star \star \star}\end{array}$ \\
\hline \multicolumn{5}{|c|}{ Demographics } \\
\hline \multicolumn{5}{|l|}{ Age, yrs } \\
\hline $18-64$ & 131,034 & 25318 (19.32) & 1 & 1 \\
\hline$\geq 65$ & 250,173 & 48716 (19.47) & $\begin{array}{l}1.01(0.99- \\
1.03)\end{array}$ & $\begin{array}{l}0.85(0.83- \\
0.87)^{\star \star \star}\end{array}$ \\
\hline \multicolumn{5}{|l|}{ Sex } \\
\hline Female & 147,147 & $24875(16.90)$ & 1 & 1 \\
\hline Male & 234,060 & 49159 (21.00) & $\begin{array}{l}1.31(1.29- \\
1.33)^{\star \star \star}\end{array}$ & $\begin{array}{l}1.31(1.29- \\
1.34)^{\star \star \star}\end{array}$ \\
\hline \multicolumn{5}{|l|}{ Income level } \\
\hline Low & 64,059 & $13046(20.37)$ & 1 & 1 \\
\hline Intermediate & 195,861 & 37507 (19.15) & $\begin{array}{l}0.93(0.91- \\
0.95)^{\star \star \star}\end{array}$ & $\begin{array}{l}0.97(0.95- \\
0.99)^{\star \star}\end{array}$ \\
\hline High & 121,287 & 23481 (19.36) & $\begin{array}{l}0.94(0.92- \\
0.96)^{\star \star \star}\end{array}$ & $\begin{array}{l}0.99(0.97- \\
1.01)\end{array}$ \\
\hline \multicolumn{5}{|l|}{ Urbanization } \\
\hline Rural & 44575 & 8754 (19.64) & 1 & 1 \\
\hline Suburban & 232349 & $45238(19.47)$ & $\begin{array}{l}0.99(0.96- \\
1.02)\end{array}$ & $\begin{array}{l}0.99(0.96- \\
1.01)\end{array}$ \\
\hline Urban & 104283 & 20042 (19.22) & $\begin{array}{l}0.97(0.95- \\
1.00)\end{array}$ & $\begin{array}{l}0.98(0.95- \\
1.01)\end{array}$ \\
\hline
\end{tabular}




\begin{tabular}{|c|c|c|c|c|}
\hline \multirow[t]{2}{*}{ Variables } & \multirow[t]{2}{*}{$\begin{array}{l}\text { Number of } \\
\text { patients }\end{array}$} & \multirow{2}{*}{$\begin{array}{l}\begin{array}{l}\text { Life-sustaining } \\
\text { treatments }^{\mathrm{a}}\end{array} \\
\mathrm{n}(\%)\end{array}$} & Univariate & \multirow{2}{*}{$\begin{array}{l}\text { Multivariate } \\
\text { analysis }\end{array}$} \\
\hline & & & OR (95\% Cl) & \\
\hline \multicolumn{5}{|l|}{ Diabetes } \\
\hline No & 245,321 & $45400(18.51)$ & 1 & 1 \\
\hline Yes & 135,886 & $28634(21.07)$ & $\begin{array}{l}1.18(1.16- \\
1.20)^{\star \star \star}\end{array}$ & $\begin{array}{l}1.11(1.09- \\
1.13)^{\star \star \star}\end{array}$ \\
\hline \multicolumn{5}{|c|}{$\begin{array}{l}\text { Chronic kidney } \\
\text { disease }\end{array}$} \\
\hline No & 293,811 & 54038 (18.39) & 1 & 1 \\
\hline Yes & 87,396 & 19996 (22.88) & $\begin{array}{l}1.32(1.29- \\
1.34)^{\star \star \star}\end{array}$ & $\begin{array}{l}1.21(1.19- \\
1.24)^{\star \star \star}\end{array}$ \\
\hline \multicolumn{5}{|c|}{$\begin{array}{l}\text { Congestive heart } \\
\text { failure }\end{array}$} \\
\hline No & 321,211 & $59746(18.60)$ & 1 & 1 \\
\hline Yes & 59,996 & $14288(23.81)$ & $\begin{array}{l}1.37(1.34- \\
1.40)^{\star \star \star}\end{array}$ & $\begin{array}{l}1.24(1.21- \\
1.27)^{\star \star \star}\end{array}$ \\
\hline \multicolumn{5}{|c|}{$\begin{array}{l}\text { Coronary heart } \\
\text { disease }\end{array}$} \\
\hline No & 257,137 & 46786 (18.19) & 1 & 1 \\
\hline Yes & 124,070 & $27248(21.96)$ & $\begin{array}{l}1.27(1.24- \\
1.29)^{\star \star \star}\end{array}$ & $\begin{array}{l}1.14(1.12- \\
1.16)^{\star \star \star}\end{array}$ \\
\hline \multicolumn{5}{|c|}{ Liver cirrhosis } \\
\hline No & 323,952 & 63979 (19.75) & 1 & 1 \\
\hline Yes & 57,255 & 10055 (17.56) & $\begin{array}{l}0.87(0.85- \\
0.89)^{\star \star \star}\end{array}$ & $\begin{array}{l}0.84(0.82- \\
0.86)^{\star \star \star}\end{array}$ \\
\hline \multicolumn{5}{|l|}{ COPD } \\
\hline No & 262,862 & 49016 (18.65) & 1 & 1 \\
\hline Yes & 118,345 & $25018(21.14)$ & $\begin{array}{l}1.17(1.15- \\
1.19)^{\star \star \star}\end{array}$ & $\begin{array}{l}1.05(1.04- \\
1.07)^{\star \star \star}\end{array}$ \\
\hline \multicolumn{5}{|l|}{ Dementia } \\
\hline No & 343,805 & $66583(19.37)$ & 1 & 1 \\
\hline
\end{tabular}




\begin{tabular}{|c|c|c|c|c|}
\hline \multirow[t]{2}{*}{ Variables } & \multirow[t]{2}{*}{$\begin{array}{l}\text { Number of } \\
\text { patients }\end{array}$} & \multirow{2}{*}{ 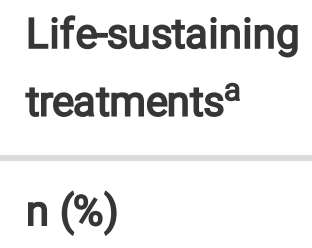 } & Univariate & \multirow{2}{*}{$\begin{array}{l}\text { Multivariate } \\
\text { analysis } \\
\text { AOR }(95 \% \mathrm{Cl})\end{array}$} \\
\hline & & & OR $(95 \% \mathrm{Cl})$ & \\
\hline Yes & 37,402 & 7451 (19.92) & $\begin{array}{l}1.04(1.01- \\
1.06)^{\star \star}\end{array}$ & $\begin{array}{l}0.95(0.92- \\
0.97)^{\star \star \star}\end{array}$ \\
\hline \multicolumn{5}{|c|}{$\begin{array}{l}\text { Cerebrovascular } \\
\text { disease }\end{array}$} \\
\hline No & 278,593 & $51892(18.63)$ & 1 & 1 \\
\hline Yes & 102,614 & $22142(21.58)$ & $\begin{array}{l}1.20(1.18- \\
1.22)^{\star \star \star}\end{array}$ & $\begin{array}{l}1.11(1.09- \\
1.14)^{\star \star \star}\end{array}$ \\
\hline \multicolumn{5}{|c|}{${ }^{* *}<.01,{ }^{\star \star *}<.001$} \\
\hline \multicolumn{5}{|c|}{$\begin{array}{l}\text { AOR adjusted odds ratio, Cl confident interval, EOL end-of-life, COPD chronic obstructive pulmonary } \\
\text { disease. }\end{array}$} \\
\hline \multicolumn{5}{|c|}{${ }^{\mathrm{a} D}$ uring the last 3 months of life. } \\
\hline
\end{tabular}


Table 3

Multivariate analysis for the association of end-of-life discussions with cardiopulmonary resuscitation, endotracheal intubation, and defibrillation in deceased cancer patients

\begin{tabular}{|c|c|c|c|}
\hline \multirow[t]{2}{*}{ Variables } & $\begin{array}{l}\text { Cardiopulmonary } \\
\text { resuscitation }^{\mathrm{a}}\end{array}$ & Intubation ${ }^{a}$ & Defibrillation ${ }^{a}$ \\
\hline & AOR (95\% Cl) & AOR (95\% Cl) & AOR (95\% Cl) \\
\hline EOL discussions & $0.43(0.41-0.45)^{\star \star \star}$ & $\begin{array}{l}0.87(0.85- \\
0.89)^{\star \star \star}\end{array}$ & $\begin{array}{l}0.52(0.48- \\
0.57)^{\star \star \star \star}\end{array}$ \\
\hline \multicolumn{4}{|l|}{ Age, yrs } \\
\hline $18-64$ & 1 & 1 & 1 \\
\hline$\geq 65$ & $0.90(0.87-0.92)^{\star \star \star}$ & $\begin{array}{l}0.86(0.84- \\
0.87)^{\star \star \star}\end{array}$ & $\begin{array}{l}0.74(0.70- \\
0.79)^{\star \star \star}\end{array}$ \\
\hline Male gender & $1.24(1.21-1.27)^{\star \star \star}$ & $\begin{array}{l}1.31(1.28- \\
1.33)^{\star \star \star}\end{array}$ & $\begin{array}{l}1.31(1.24- \\
1.38)^{\star \star \star}\end{array}$ \\
\hline \multicolumn{4}{|l|}{ Income level } \\
\hline Low & 1 & 1 & 1 \\
\hline Intermediate & $0.92(0.90-0.95)^{\star \star \star}$ & $\begin{array}{l}0.98(0.96- \\
1.01)\end{array}$ & $\begin{array}{l}1.10(1.02- \\
1.18)^{\star}\end{array}$ \\
\hline High & $0.91(0.88-0.94)^{\star \star \star}$ & $\begin{array}{l}1.00(0.98- \\
1.03)\end{array}$ & $\begin{array}{l}1.17(1.08- \\
1.26)^{\star \star \star}\end{array}$ \\
\hline \multicolumn{4}{|l|}{ Urbanization } \\
\hline Rural & 1 & 1 & 1 \\
\hline Suburban & $1.00(0.97-1.04)$ & $\begin{array}{l}0.98(0.96- \\
1.01)\end{array}$ & $\begin{array}{l}1.03(0.95- \\
1.11)\end{array}$ \\
\hline Urban & $1.02(0.97-1.06)$ & $\begin{array}{l}0.96(0.93- \\
0.99)^{\star \star}\end{array}$ & $\begin{array}{l}1.10(1.00- \\
1.20)^{\star}\end{array}$ \\
\hline \multicolumn{4}{|l|}{ Comorbidity } \\
\hline Diabetes & $1.14(1.12-1.17)^{\star \star \star}$ & $\begin{array}{l}1.11(1.09- \\
1.13)^{\star \star \star}\end{array}$ & $\begin{array}{l}1.17(1.11- \\
1.24)^{\star \star \star}\end{array}$ \\
\hline $\begin{array}{l}\text { Chronic kidney } \\
\text { disease }\end{array}$ & $1.18(1.15-1.22)^{\star \star \star}$ & $\begin{array}{l}1.21(1.19- \\
1.24)^{\star \star \star}\end{array}$ & $\begin{array}{l}1.31(1.24- \\
1.38)^{\star \star \star}\end{array}$ \\
\hline $\begin{array}{l}\text { Congestive heart } \\
\text { failure }\end{array}$ & $1.35(1.31-1.39)^{\star \star \star}$ & $\begin{array}{l}1.22(1.19- \\
1.25)^{\star \star \star}\end{array}$ & $\begin{array}{l}1.97(1.85- \\
2.09)^{\star \star \star}\end{array}$ \\
\hline
\end{tabular}




\begin{tabular}{|c|c|c|c|}
\hline \multirow[t]{2}{*}{ Variables } & $\begin{array}{l}\text { Cardiopulmonary } \\
\text { resuscitation }^{\mathrm{a}}\end{array}$ & \multicolumn{2}{|c|}{ resuscitation ${ }^{a}$} \\
\hline & AOR (95\% Cl) & AOR (95\% Cl) & AOR $(95 \% \mathrm{Cl})$ \\
\hline $\begin{array}{l}\text { Coronary heart } \\
\text { disease }\end{array}$ & $1.22(1.19-1.25)^{\star \star \star}$ & $\begin{array}{l}1.14(1.12- \\
1.16)^{\star \star \star}\end{array}$ & $\begin{array}{l}1.60(1.51- \\
1.69)^{\star \star \star}\end{array}$ \\
\hline Liver cirrhosis & $0.68(0.66-0.71)^{\star \star \star}$ & $\begin{array}{l}0.86(0.84- \\
0.89)^{\star \star \star}\end{array}$ & $\begin{array}{l}0.71(0.65- \\
0.76)^{\star \star \star}\end{array}$ \\
\hline COPD & $1.03(1.01-1.06)^{*}$ & $\begin{array}{l}1.04(1.02- \\
1.06)^{\star \star \star}\end{array}$ & $\begin{array}{l}0.87(0.82- \\
0.92)^{\star \star \star}\end{array}$ \\
\hline Dementia & $1.05(1.01-1.09)^{*}$ & $\begin{array}{l}0.92(0.89- \\
0.95)^{\star \star \star}\end{array}$ & $\begin{array}{l}0.79(0.72- \\
0.86)^{\star \star \star}\end{array}$ \\
\hline $\begin{array}{l}\text { Cerebrovascular } \\
\text { disease }\end{array}$ & $1.03(1.00-1.06)$ & $\begin{array}{l}1.12(1.10- \\
1.14)^{\star \star \star}\end{array}$ & $\begin{array}{l}0.97(0.91- \\
1.02)\end{array}$ \\
\hline \multicolumn{4}{|l|}{${ }^{*}<.05,{ }^{* \star *}<.001$} \\
\hline \multicolumn{4}{|c|}{$\begin{array}{l}\text { AOR adjusted odds ratio, } \mathrm{Cl} \text { confident interval, EOL end-of-life, COPD chronic obstructive pulmonary } \\
\text { disease. }\end{array}$} \\
\hline \multicolumn{4}{|c|}{ aD During last 3 months of life. } \\
\hline
\end{tabular}


Table 4

Sensitivity analysis for the associations between end-of-life discussions and life-sustaining treatment after adjusting for patient characteristics

\begin{tabular}{|c|c|c|c|c|}
\hline \multirow[t]{2}{*}{ Study subgroups } & $\begin{array}{l}\text { Life-sustaining } \\
\text { treatments }\end{array}$ & $\begin{array}{l}\text { Cardiopulmonary } \\
\text { resuscitation }\end{array}$ & $\begin{array}{l}\text { Endotracheal } \\
\text { intubation }\end{array}$ & Defibrillation \\
\hline & \multicolumn{4}{|l|}{ AOR (95\% Cl) } \\
\hline $\begin{array}{l}\text { All patients }(\mathrm{n}= \\
381207)\end{array}$ & $\begin{array}{l}0.82(0.80- \\
0.84)^{\star \star \star}\end{array}$ & $0.43(0.41-0.45)^{\star \star \star}$ & $\begin{array}{l}0.87(0.85- \\
0.89)^{\star \star \star}\end{array}$ & $\begin{array}{l}0.52(0.48- \\
0.57)^{\star \star \star}\end{array}$ \\
\hline $\begin{array}{l}\text { Aged 18-64 }(n= \\
131034)\end{array}$ & $\begin{array}{l}0.83(0.80- \\
0.87)^{\star \star \star}\end{array}$ & $0.46(0.42-0.49)^{\star \star \star}$ & $\begin{array}{l}0.88(0.85- \\
0.92)^{\star \star \star}\end{array}$ & $\begin{array}{l}0.57(0.49- \\
0.65)^{\star \star \star}\end{array}$ \\
\hline $\begin{array}{l}\text { Aged } \geq 65(n= \\
250173)\end{array}$ & $\begin{array}{l}0.82(0.79- \\
0.84)^{\star \star \star}\end{array}$ & $0.42(0.40-0.44)^{\star \star \star}$ & $\begin{array}{l}0.86(0.84- \\
0.89)^{\star \star \star}\end{array}$ & $\begin{array}{l}0.50(0.45- \\
0.56)^{\star \star \star}\end{array}$ \\
\hline $\begin{array}{l}\text { Female patients }(\mathrm{n} \\
=147147)\end{array}$ & $\begin{array}{l}0.82(0.79- \\
0.85)^{\star \star \star}\end{array}$ & $0.43(0.40-0.47)^{\star \star \star}$ & $\begin{array}{l}0.86(0.83- \\
0.90)^{\star \star \star}\end{array}$ & $\begin{array}{l}0.51(0.44- \\
0.60)^{\star \star \star}\end{array}$ \\
\hline $\begin{array}{l}\text { Male patients }(n= \\
234060)\end{array}$ & $\begin{array}{l}0.83(0.80- \\
0.85)^{\star \star \star}\end{array}$ & $0.43(0.41-0.46)^{\star \star \star}$ & $\begin{array}{l}0.87(0.85- \\
0.90)^{\star \star \star}\end{array}$ & $\begin{array}{l}0.53(0.48- \\
0.60)^{\star \star \star}\end{array}$ \\
\hline \multicolumn{5}{|l|}{ *** $<.001$} \\
\hline AOR adjusted odds & Cl confident & & & \\
\hline
\end{tabular}

\section{Supplementary Files}

This is a list of supplementary files associated with this preprint. Click to download.

- Supplementarytable1.docx 